\title{
Critical Questions of Knowledge Management Concerning Women on Maternity Leave in Hungary
}

\author{
Andrea Bencsik, Timea Juhasz, Renata Machova, \\ Zsuzsanna Toth
}

J. Selye University, Bratislavska cesta 3322, SK-94501 Komarno, Slovakia

e-mail: bencsika@ujs.sk; machovar@selyeuni.sk; tothz@ujs.sk

\begin{abstract}
Hungarian organizations have to solve a lot of problems when their female employees take maternity leave and mothers may stay at home, with their child, for up to three years. During this long period of time, organizations have to organize her substitute, and, more importantly, they also have to insure that her knowledge stays relevant to the organization. Empirical research was conducted last year, concerning the knowledge management processes applied, when a member of the organization goes on maternity leave. Research questions: What can the employer and the employee do in this situation to make the knowledge transfer processes optimal? Also, do both sides feel this knowledge transfer is in their best interest? It is important because preserving knowledge is vital for a company in this special situation. The current article examines these critical questions from the point of view of employers and employees alike. The authors studied whether the career opportunities and the position of employees influence the success of knowledge transfer and whether employers expect special knowledge from their employees. The research was conducted in 2013-2014 in the form of a qualitative and quantitative survey. The results showed that, regarding women on maternity leave, the knowledge transfer conducted, during their materity leave, was not affected by their position and career prospects at the organization; similarly, the process was not significantly influenced by whether the organizations expected specialized knowledge from their employees or not.
\end{abstract}

Keywords: knowledge management; maternity leave; motherhood; knowledge transfer; Hungarian practice; labor market

\section{Introduction}

The member states of the European Union follow different maternity leave practices concerning the entitlement and duration of maternity leave. Hungary is one of those EU member states where both the mother and the father are entitled to stay at home with the child from the beginning - for a longer or shorter period of time. The fact, however, is that the duration of this maternity leave, is one of 
the longest in the EU, and many Hungarian families do take advantage of this opportunity.

Their long absence from the labor market is essentially an employment question, both in the case of the employer and the employee who would eventually return to work. The question is whether this long absence will prove to be advantageous or disadvantageous for their later employment. Last year, comprehensive research was conducted to find out what questions and protocols occur at the organizations when one of their female employees goes on maternity leave. How is their knowledge transferred and retained within the organization, and whether or not the two sides feel it is their interest for this knowledge to be retained by the organization while the employee is away?

In order to examine this question, qualitative and quantitative research was conducted among employers and employees alike. The research helped to understand the most timely questions and solutions, which both sides considered important. This article presents some results from the research done among both sides, in order to verify the hypotheses described in the research.

\section{Sate of Art}

\subsection{Some Thoughts Concerning the Hungarian Practice}

Before giving a detailed introduction, it may be worth having a brief look at the Hungarian practice regarding these situations.

As it has already been mentioned in the introduction, maternity leave can be very long in Hungary. As a basis, maternity leave may last up to three years from the birth of the child, but if more children are born in the family during this period, the mother may stay away from the labor market for as long as 6-8 years. This is an opportunity which is typically taken by a woman within a family. However, researchers disagree about the ideal length of absence for these women.

Families will get a number of types of financial support that could inspire them to stay at home. Thus, parents taking care of the child will get GYED (child care allowance) until the child reaches the age of 2, or if somebody is not entitled to this, she can get GYES (child care benefit) until the child reaches the age of 3 [30].

However, Bálint-Köllö [4] also calls attention to the fact that the grants which women may apply irrespectively of whether they are active on the labor market or not (like GYES and GYED) strengthen the value of home and may motivate mothers to stay away from work for a longer period of time. 
To insure employer interest in hiring employees returning from maternity leave, several employment grants are allotted to them. We can see that this employment policy encourages employers to be open to re-employing these workers.

Research in 2008 [6] found that mothers of young children returning from GYES or GYED face great difficulties reconciling their family (and other external) commitments with the demands of their employers. Also, their long absence from work affected the value of their professional knowledge, which often caused uncertainty and self-esteem problems during their re-integration [26]. Only 54.6\% of the 252 women interviewed in the research from 2008 felt their knowledge was up-to-date on their return to work, and only $58 \%$ of them trained themselves at home to meet the expectations of the labor market.

According to professional literature, knowledge is valuable whether it is tacit or explicit [33], and every individual and organization should take this into consideration if they want to retain their competitive lead [25]. Leonards [32] defined the basic abilities, that is, knowledge assets, which ensure competitiveness. Human capital appears these days as a category of intellectual capital in professional literature [23]. At the same time a modern HRM today has to conform to the requirements of knowledge-based economies and organizations [15]. An employee with knowledge and skills which are useful to the organization means a valuable asset to the organization, and this knowledge may become the main source of its competitive asset.

For a long time, knowledge management literature has been examining the creation, retention, transfer and utilization of knowledge capital in order to ensure the competitive asset of the organization. The question of how and to whom organizational knowledge may be linked and how this type of knowledge may be transferred has also been in the focus of researchers for a long time [9].

Professional literature [3] considers knowledge transfer as spreading knowledge among individuals and groups within the organization, and this pursuit forms the basis of corporate competitiveness improvement.

From the point of view of knowledge management, the most important elements of organizational culture are trust, communication, and learning. An inappropriate organizational culture may hinder any kind of knowledge building [19], as one of the hardest tasks for a manager is to decide what kind of culture can acquire and process the new knowledge.

According to Davenport and Prusak [18], effective knowledge transfer within an organization is mostly hindered by a lack of trust between the management and the employees. One of the reasons for this mistrust is the power distance between management and their workers: as a result, employees often do not see their leaders as partners at work [5]. This often causes employees to try to retain their knowledge monopoly and consequently, their status [21; 13]. In many cases, this hinders proper knowledge transfer within the organization. 


\subsection{What We Should Know about Trust}

Trust is the base of knowledge sharing in the special situation examined later by the authors. Professional literature examines its role from several aspects in the process of knowledge management, thus it is important to review its relevant features.

Davenport and Prusak [17] claim that knowledge sharing as a requirement is unnatural as people believe that their individual knowledge is important and valuable. This mentality naturally results in hoarding knowledge and a general mistrust towards knowledge coming from other people.

Trust is a capital resource that creates new intellectual capital through the mechanics of combining and sharing knowledge. As a result, trust has a special significance, especially in an innovative environment. Trust is a category of managerial abilities which also defines the relationship between leaders and colleagues. Those employees who trust their superiors are more creative, more willing to take risks and more cooperative [20].

Boon and Holmes [12] claim that trust changes in time, as people become more and more comfortable in the presence of others and as they experience how trustworthy and competent the others are.

Cook and Wall [16] also make a distinction between trust in the management and trust between equal partners. They pointed out that trust at the workplace has a strong effect on several organizational phenomena like contentedness at the workplace, stress, organization commitment, productivity and, which is the most important in this research, knowledge sharing.

Abrams et al. [1] claim that trust results in increased and comprehensive knowledge sharing, which makes the process less costly and increases the chance that the knowledge gained from a colleague will be deeper, better understood and overall more useful this way.

We can see from this short review, that the issue of trust, has a key position in the research of several experts and it is no wonder that it has been the center of dependency studies concerning knowledge sharing for many years. Although the target areas and subjects of the research differs, the conclusions overlap as all studies emphasize that knowledge sharing remains an illusion, without trust between the people involved in the process.

Building trust within the organization is not quite the same as building trust between individuals [14]. Alston and Tippett [2] drew this conclusion after studying various research, focusing on organizational culture. They believe that culture and trust both play very distinctive roles in the operation of an organization. Organizational trust can be seen as a multi-level phenomenon which is closely linked to the norms, values and beliefs found in the organizational culture itself. 
The basic condition of knowledge transfer is that its participants should speak a "common language," as forming mutual trust and understanding is indispensable. This does not only mean what we traditionally understand as 'language,' but it also includes professional language and a similar degree of professional skill. Personal communication is also vitally important. Physical proximity, similar interests and experience are all factors which contribute to the mutual trust formed between the participants, which in turn persuades them to share their knowledge and experience [10].

Knowledge transfer is only completely successful if it results in some degree of change in attitude, behavior, and it raises new ideas [28].

A well-chosen knowledge sharing tool set has a vital role here as well as its correct application and the conditions of its application [8]. The role of HR is further strengthened by the fact that the correct and unhindered application of knowledge transfer (especially in the case of tacit knowledge) cannot happen without ensuring certain conditions regarding culture forming, ethical behavior, leadership examples etc. handling all these factors is the task of the HR department.

Current research is examining what kind of value the knowledge of employees about to go on maternity leave really represents. Specifically how much of this knowledge can be tied to their personality and in what ways the organizations expect to cope with the loss of knowledge.

The research was conducted between 2013 and 2014, using a Hungarian sample, which means the results and correlations are also typical of the Hungarian practice. The project was called 'Knowledge Transfer and Retention among Mothers of Young Children.' The essential point of the sampling was that the opinion of both sides should be seen, so research was done among employees and employers alike. As for the employees, the people who were sampled had all been on maternity leave for a certain amount of time. Regarding the employers, the respondents had either employed people freshly returning from GYES or GYED, or they had an active protocol designed specifically to deal with similar situations. The examination of both sides had two phases. The first was qualitative research with the aim to get to know the problem and the results were used to launch the second, quantitative phase in order to reveal the connections. In-depth interviews were carried out in qualitative research, while in case of the quantitative research, questionnaires were applied in an on-line form. The research results of the two sides will be presented separately to prove the stated hypotheses. 


\section{Methodology of Research among the Women}

\subsection{Qualitative Research among the Women}

The first part of the research conducted among the women was an exploratory, information gathering examination, with in-depth interviews used as a tool. Using the results of these in-depth interviews, qualitative research was conducted later in order to examine the validity of the hypothesis; the aim was to reveal the connections. The interviews were conducted among 11 respondents. The aim of this article is not to give a detailed account of the results of the interviews: only the most important findings are presented in the following:

- Several organizations realized that they needed to retain the knowledge possessed by their female employees about to go on maternity leave. This realization was more prevalent among the companies where the management had already made steps to develop and retain the knowledge of their employees.

- People taking part in this process found that not all knowledge can be transferred as some of it is added value, depending on the personality of the individual; this knowledge could not be, or could barely be shared.

- The women were aware that their long absence from work affected their professional knowledge, but they did not always do anything to keep their knowledge up-to-date and valuable for their return to work.

- Women returning from maternity leave did not trust the labor-market value of their own knowledge, which caused serious self-esteem problems among several respondents. This had a negative effect on their self-confidence and motivation for re-integration, which in turn affected their successful employment in a negative way.

- The research also showed that not only the open and positive motivation of the mothers is needed in the knowledge transfer process, but it is also necessary to have a supportive organization culture which has already incorporated knowledge management into its everyday practice.

\subsection{Quantitative Research among the Women}

The interviews done with the mothers made it possible to learn about the questions arising in this particular situation; the reasons and connections will have to be revealed with quantitative research. Based on the qualitative questionnaire, a hypothesis was made, which relied on the experience gained during the in-depth interview; its validity was also supported by quantitative research: 


\section{Hypothesis}

1) Regarding the women taking part in the research, before they went on maternity leave, the success of their knowledge transfer had been influenced by their career prospects and current position in their organization.

\subsubsection{Sampling}

The sampling method used was the snowball method, and so the research cannot be considered representative. As it has already been mentioned, the mothers could fill in the questionnaire online. It was seen even during the in-depth interviews that the women were reluctant to speak about certain topics; the knowledge management questions and experiences during their return to work were among these, mostly because of self-esteem problems. Before the actual release, the questionnaire had been tested in cooperation with 4 women; they had no problem interpreting the questionnaire and the questionaire remained unchanged, as a consequence. The authors applied the snowball-method in collecting the samples by involving organizations, of which the main profile was helping mothers find employment. This method guaranteed the best availability of the people concerned and the highest number of questionnaires. The on-line questionnaire was used on a voluntary basis and was anonymous; the results were processed with SPSS. The final sample number was 263 and there was no sample, which had to be left out of the research because it could not be assessed. The specific data is presented in the following Table 1 .

Table 1

Specification of the Sample of Mothers with Young Children

\begin{tabular}{|l|l|}
\hline $\begin{array}{l}\text { Regional } \\
\text { Division of } \\
\text { Sample }\end{array}$ & $\begin{array}{l}\text { 65.8\% Central Hungary, 20.2\% Northern-Hungary, 6.1\% Western- } \\
\text { Transdanubia, 4.6\% Northern Great Plain, 3\% Southern Great Plain, } \\
0.3 \% \text { Southern-Transdanubia }\end{array}$ \\
\hline Age & $19.8 \%$ under 20, 58.6\% between 31-40, 21.6\% over 40 \\
\hline Family Status & $\begin{array}{l}\text { 70\% Married, 16\% Stable relationship, 8\% Divorced, 5.3\% Single, } \\
0.7 \% \text { Other }\end{array}$ \\
\hline $\begin{array}{l}\text { Number of } \\
\text { Children }\end{array}$ & $\begin{array}{l}46.4 \% \text { Raising 1 child, 38\% Raising 2 children, 13.7\% Raising 3 } \\
\text { children, 1.9\% Raising 4 or more children }\end{array}$ \\
\hline $\begin{array}{l}\text { Highest level of } \\
\text { Qualification }\end{array}$ & $\begin{array}{l}5.3 \% \text { no secondary degree, 35.7\% secondary degree, 57.8\% tertiary } \\
\text { degree, 1.2\% PhD grads }\end{array}$ \\
\hline
\end{tabular}

The women could fill in the internet questionnaire anonymously. There were mostly closed questions with only 3 open questions among them. The questionnaire examined 4 life situations, the question groups of which are summarized - partially - in Table 2 . 
Table 2

System of Questionnaire for Mothers of Young Children

\begin{tabular}{|c|c|}
\hline \multirow{3}{*}{$\begin{array}{c}\text { Life Situation } \\
1 \text { (before } \\
\text { Having a } \\
\text { Child) }\end{array}$} & the organization? \\
\hline & What career prospects did she have within the organization? \\
\hline & $\begin{array}{l}\text { How was the knowledge management process implemented in the } \\
\text { organization? }\end{array}$ \\
\hline \multirow{3}{*}{$\begin{array}{l}\text { Life Situation } \\
2 \text { (Pregnancy) }\end{array}$} & How did the organization manage to replace the mother? \\
\hline & What tasks did the mother have during the knowledge transfer? \\
\hline & What were the positive and negative features of the knowledge transfer? \\
\hline \multirow{3}{*}{$\begin{array}{l}\text { Life Situation } \\
3 \text { (Raising the } \\
\text { Child at } \\
\text { Home) }\end{array}$} & What knowledge elements are active and passive at home? \\
\hline & $\begin{array}{l}\text { What is the knowledge management practice towards employees staying } \\
\text { at home? }\end{array}$ \\
\hline & $\begin{array}{l}\text { What are the methods and cooperative opportunities of knowledge } \\
\text { refreshment and development with and without the help of the } \\
\text { organization? }\end{array}$ \\
\hline \multirow{3}{*}{$\begin{array}{l}\text { Life Situation } \\
4 \text { (Returning } \\
\text { to Work after } \\
\text { Maternity } \\
\text { leave) }\end{array}$} & $\begin{array}{l}\text { What chances of return do women have after their maternity leave } \\
\text { expires? }\end{array}$ \\
\hline & $\begin{array}{l}\text { What kind of knowledge management tasks do women and their } \\
\text { organizations have in this situation? }\end{array}$ \\
\hline & dge transfer loss \\
\hline
\end{tabular}

\section{Interpretation of Research among the Women}

Evaluating the results of the questionnaire was done with the help of one- and multiple-variable statistical methods. The one-variable methods were frequency, average and deviation procedures, while the multiple-variable methods included cross-table analysis and ANOVA. The data were evaluated by the SPSS statistical program. The cross-table analysis made it possible to show the similarities and differences between the nominal variables, while in the case of the ANOVAstudies, a one- and multiple-way analysis was done. With the help of the latter, the effect of the nominal variables and their interaction could be examined on the metric variables (5-point Likert scales).

The questionnaire wanted to detrermine what positions the respondents had occupied before having the baby. $76 \%$ of the women asked, claimed they were employees, while $5.3 \%, 10.3 \%$ and $1.9 \%$ were low-, mid- and top-level managers. $3.8 \%$ had their own business, while $2.7 \%$ had not been employed prior to their pregnancy. During the research, three groups were made from the respondents: employees, managers and the people without employment during their pregnancy. Those people who were not employed prior to their pregnancy were left out of the sample, which means the final examination was conducted on 256 women. 
Approximately $55.1 \%$ of the respondents had career prospects at their organization before going on maternity leave. $63.7 \%$ of the respondents had been studying continuously before their pregnancy because of their job. $70.7 \%$ of the women taking part in the research were assisted by their employers before their pregnancy to keep their knowledge up-to-date.

The respondents believed that the most effective form of learning before their pregnancy was studying within the organization (40.2\%), while about a third of them believed in self-studies and $29.7 \%$ saw no difference in the efficiency of studying by themselves or at a organization course.

On announcing the pregnancy, companies had to make sure that a medium or long-term replacement for their employee was available. The reactions of the employers varied wildly. $44.9 \%$ of the respondents said their employer was happy about their pregnancy, while $18 \%$ claimed their employers were not happy and $29.7 \%$ claimed their superiors were indifferent. As it turned out from the answers, $58.2 \%$ of the women claimed their employer hired a new colleague to replace them, while $19.1 \%$ solved this problem with re-organization, $18.8 \%$ divided the extra work among the remaining workers, $2.7 \%$ mentioned another method and about $1.2 \%$ had to realize that their position was discontinued altogether. It must be pointed out, however, that the Labor Code guarantees that the mother cannot be dismissed from work during their paid leave, that is, legislation limited the options of the employers in this respect.

The research also examined how mothers of young children consider passing their knowledge on before maternity leave advisable. The question was how do career prospects and positions influence women in their decision to take part in the knowledge transfer on their own before leaving. Claims were made which could be graded by the respondents on a 5-point Likert scale. 1 meant 'strongly disagree', while 5 meant 'strongly agree'. The research was done with multipleway variant analysis, where the statements were the dependent variants, the career prospects and job positions were the independent ones; the subject of the examination also included their separate effects as well as their mutual (interactive) effects on the dependent variable. Table 3 presents some of the statements:

Table 3

Frequency, Average and Standard Deviation of the Answers Regarding Knowledge Transfer

\begin{tabular}{|c|c|c|c|c|c|}
\hline Statement & Agrees & Frequency & Valid Percent & AVG & SD \\
\hline \multirow{6}{*}{$\begin{array}{l}\text { If a mother of young } \\
\text { children goes on } \\
\text { GYES and GYED, she } \\
\text { should definitely pass } \\
\text { her tasks and } \\
\text { knowledge to the } \\
\text { organization. }\end{array}$} & Strongly disagree & 7 & 2.7 & \multirow{6}{*}{3.98} & \multirow{6}{*}{1.061} \\
\hline & Rather disagree & 14 & 5.5 & & \\
\hline & $\begin{array}{c}\text { Equally agree and } \\
\text { disagree }\end{array}$ & 62 & 24.2 & & \\
\hline & Rather agree & 67 & 26.2 & & \\
\hline & Strongly agree & 106 & 41.4 & & \\
\hline & Total & 256 & 100 & & \\
\hline
\end{tabular}




\begin{tabular}{|c|c|c|c|c|c|}
\hline Statement & Agrees & Frequency & Valid Percent & AVG & SD \\
\hline \multirow{6}{*}{$\begin{array}{l}\text { If a mother of young } \\
\text { children goes on } \\
\text { GYES and GYED, she } \\
\text { can pass all her } \\
\text { knowledge to her } \\
\text { organization. }\end{array}$} & Strongly disagree & 22 & 8.6 & \multirow{6}{*}{2.96} & \multirow{6}{*}{1.062} \\
\hline & Rather disagree & 60 & 23.4 & & \\
\hline & $\begin{array}{c}\text { Equally agree and } \\
\text { disagree }\end{array}$ & 103 & 40.2 & & \\
\hline & Rather agree & 48 & 18.8 & & \\
\hline & Strongly agree & 23 & 9.0 & & \\
\hline & Total & 256 & 100.0 & & \\
\hline Statement & Agrees & Frequency & Valid Percent & AVG & SD \\
\hline \multirow{6}{*}{$\begin{array}{l}\text { If a mother of young } \\
\text { children goes on } \\
\text { GYES or GYED, it is } \\
\text { not reasonable to pass } \\
\text { all her knowledge to } \\
\text { her organization. }\end{array}$} & Strongly disagree & 72 & 28.1 & \multirow{6}{*}{2.57} & \multirow{6}{*}{1.318} \\
\hline & Rather disagree & 57 & 22.3 & & \\
\hline & $\begin{array}{c}\text { Equally agree and } \\
\text { disagree }\end{array}$ & 63 & 24.6 & & \\
\hline & Rather agree & 37 & 14.5 & & \\
\hline & Strongly agree & 27 & 10.5 & & \\
\hline & Total & 256 & 100 & & \\
\hline
\end{tabular}

The results of the research clearly show that most women feel that knowledge transfer is important in this situation -with about $67.6 \%$ of the respondents agreeing - the deviation was one of the smallest in this question. At the same time, the research also revealed that these women could not share every piece of knowledge with their replacement. Concerning the findings of the in-depth interviews it has already been mentioned that organization-specific knowledge is relatively easier to pass on than the knowledge tied to emotional intelligence because the latter is personality-dependent. Typically, the respondents felt that these areas were exactly the ones where knowledge was lost during the transfer. $21.5 \%$ of the women who filled in the questionnaire mentioned that there were pieces of information which they could not share with their replacement. They believed the areas where they could share the least amount of knowledge were the following: connection network, task-solving abilities, emotional intelligence, communication skills and professional knowledge. It is clear that emotional intelligence could either not be shared or it can be passed on only with great difficulty.

The question, however, is whether the success of knowledge transfer is influenced by how much the women consider it in their own interest to share their knowledge with their replacement. It can be seen that about a quarter of the women believed that they might not need to share everything, that is, they felt motivated to withhold knowledge. There can be several reasons for this. By sharing all knowledge, they may feel their return to the organization will be endangered, especially because they are no longer protected from being made redundant after their child reaches 3 . At the same time, if the mother returns to work before her child is 3 , her employment may be discontinued for reasons in relation to the skills of the employee or the operation of the workplace. These reasons include a lack of 
positions which suit their skills, qualification or practice of the employee or the employee herself refusing the position offered to her. The employee may also be made redundant if - either deliberately or out of neglect - if she ignores the responsibilities which her work involves or demonstrates behavior which endangers the continuation of her employment. All the above means that if the mothers of young children do not feel their chances of return secure, they are not really motivated to share all their knowledge.

Next, the claims were evaluated through multiple-way variant analysis, where the subject of the examination was how some positions or career prospects affected a given answer. The research verified that the two independent variables were indifferent in the case of all three answers, and, similarly, the interaction of the variables had no effect on the dependent variables.

\section{Methodology of Organization Research}

\subsection{Qualitative Research among the Companies}

Besides mothers of young children, organizations were also asked about their opinion concerning the critical questions of the situation presented above. The research was conducted similarly to that of the mothers of young children, with both qualitative and quantitative methods.

Fifty companies were involved in the qualitative research with the help of an interview with a one-on-one managing HR worker. This essay will not present all the data in detail; rather, it will concentrate on the most important findings. The focus of the research was whether the participant companies were prepared with a feasible protocol for the knowledge transfer of mothers of young children temporarily going on maternity leave in order to save the knowledge capital of the pregnant employee for the organization. According to the in-depth interviews, the following statements can be made:

- Most of the examined companies realized that in this situation, that is, when a pregnant woman leaves the organization - even temporarily - conscious effort has to be made to retain her knowledge for the organization.

- There was a developed practice at most of the companies enabling them to retain the knowledge of the mothers of young children and they also encouraged the active participation of the mothers to save the greatest amount of knowledge.

- Many organizations knew that they had to face a loss of knowledge, even with the above method, but they believe that the degree of loss depends on the organizational culture, the maturity of the knowledge management practice, the replacement solution, and the mother of young children herself. 
- While mothers of young children were staying at home, most organizations had not developed protocol to assist the mothers to retain their knowledge at home.

- There was no unified practice concerning knowledge refreshment and updating mothers newly returning from maternity leave. The type of actual practice was determined by the organization activities, organization culture and the attitude of the management. Several of the examined organizations had no such practice, but the majority tried to assist young mothers to bring their knowledge up to date, usually in the form of consultation with the colleagues.

\subsection{Quantitative Research among the Companies}

Based on the findings of the in-depth interviews, quantitative research was launched among the companies. The quantitative research proved the following hypothesis:

\section{Hypothesis}

2) Among the companies taking part in the research, the success of the knowledge transfer for mothers on maternity leave is influenced by whether the employer expects special (organization-specific) knowledge from the employees or not.

\subsubsection{Sampling}

The snowball-method was the chosen sampling technique, and so, the research cannot be considered representative. The aim of the sampling was to collect samples from all Hungarian regions. Unfortunately, there are under-represented regions in the sample - for example, Southern-Transdanubia and the Southern Great Plains - where only a small number of samples were contributed. The final sample number was 80 . The features of the sample are presented below (Table 4).

Table 4

Frequency, Average and Standard Deviation of the Answers Regarding Knowledge Transfer

\begin{tabular}{|l|l|}
\hline $\begin{array}{l}\text { Regional Division } \\
\text { of Sample }\end{array}$ & $\begin{array}{l}13.8 \% \text { Northern Hungary, 3.8\% Northern Great Plains, 2.5\% } \\
\text { Southern Great Plains, 66.3\% Central Hungary, 3.8\% Central } \\
\text { Transdanubia, 8.8\% Western- Transdanubia, 1.0\% Southern- } \\
\text { Transdanubia }\end{array}$ \\
\hline $\begin{array}{l}\text { Organizational } \\
\text { Pursuits }\end{array}$ & $\begin{array}{l}18.8 \% \text { trade, repair, 18.8\% financial pursuits, 12.5\% catering, 8.8\% } \\
\text { building industry, 5\% health and social service, 5\% transport and } \\
\text { storage, 5\% estate business, econ. serv., 26.1\% other }\end{array}$ \\
\hline $\begin{array}{l}\text { Size of } \\
\text { Organization }\end{array}$ & $\begin{array}{l}28.8 \% \text { (micro-enterprise with 2-8 people), 28.8\% (small enterprise } \\
\text { with 9-49 people), 16.3\% (medium-sized enterprise with 50-249 } \\
\text { people), 26.1\% (big enterprise above 250 people) }\end{array}$ \\
\hline $\begin{array}{l}\text { Enterprise Form } \\
\text { of Organization }\end{array}$ & $\begin{array}{l}\text { 68.8\% Ltd., 20\% Ltd (close corporation), 11.3\% individual venture, } \\
\text { venture, 6.1\% other }\end{array}$ \\
\hline
\end{tabular}


The questionnaire compiled for the organizations was also available through the Internet to any organization who wished to fill it in. The questionnaire contained mostly closed questions which were built on a nominal and metric scale. Similarly to the questions aimed at the women, this questionnaire also focused on four areas which are summarized in the following Table 5.

Table 5

Questionnaire System for Organizations

\begin{tabular}{|c|c|}
\hline \multirow{5}{*}{$\begin{array}{l}\text { Life Situation } \\
1 \text { (before } \\
\text { Having a } \\
\text { Child) }\end{array}$} & $\begin{array}{l}\text { General features of the organization (pursuits, regional division, size } \\
\text { etc.) }\end{array}$ \\
\hline & $\begin{array}{l}\text { What kind of expectations are there concerning employees' knowledge } \\
\text { and skills? }\end{array}$ \\
\hline & $\begin{array}{l}\text { Is there any differentiation between employees concerning knowledge } \\
\text { and if so, how? }\end{array}$ \\
\hline & $\begin{array}{l}\text { What kind of knowledge management protocol exists within the } \\
\text { organization? }\end{array}$ \\
\hline & $\begin{array}{l}\text { How is the knowledge management process realized in the } \\
\text { organization? }\end{array}$ \\
\hline \multirow{5}{*}{$\begin{array}{l}\text { Life Situation } \\
2 \text { (Pregnancy) }\end{array}$} & How does the organization replace pregnant women? \\
\hline & What knowledge transfer tools are used in this situation? \\
\hline & What kind of knowledge can the mother choose not share? \\
\hline & What are the factors of organizing replacement? \\
\hline & What is the source of knowledge loss? \\
\hline \multirow{4}{*}{$\begin{array}{l}\text { Life Situation } \\
3 \text { (Raising the } \\
\text { Child at } \\
\text { Home) }\end{array}$} & How does the organization keep in touch with the mother on leave? \\
\hline & Which skills does the mother have to develop at home? \\
\hline & Do they help in the knowledge retaining process? How? \\
\hline & $\begin{array}{l}\text { What knowledge can the mother at home get which she can later use at } \\
\text { the organization? }\end{array}$ \\
\hline \multirow{4}{*}{$\begin{array}{l}\text { Life Situation } \\
4 \text { (Returning } \\
\text { to Work after } \\
\text { Maternity } \\
\text { leave) }\end{array}$} & Is there a return protocol for the mothers of young children? \\
\hline & Is there a knowledge assessment on the mother's return to work? \\
\hline & $\begin{array}{l}\text { What advantages and disadvantages do re-entrants have concerning } \\
\text { knowledge management? }\end{array}$ \\
\hline & What is the knowledge refreshment practice within the organization? \\
\hline
\end{tabular}

The questionnaire was mostly built on nominal and metric scales and variables.

\section{Interpretation of Research among the Companies}

The results were assessed with the help of one- and multiple-variable methods; regarding the frequency, average, deviation and multiple-variable examinations, the cross-table analysis was chosen to be used. The assessment was done with an SPSS program. 
During the examination, 'special knowledge' mostly meant the kind of specific knowledge which was valuable for the organization. $48.4 \%$ of the organizations demanded some form of special knowledge from their employees, so there was no surprise when $76.3 \%$ of the organizations also required knowledge development, that is, training. There was no significant correlation verified between the expectation for special knowledge and whether there was any need for intraorganizational training (Pearson Chi-square test: $3.078 \mathrm{df}: 1$ sign: $.079 \mathrm{p}>0.000$ ). At the same time, most organizations made no difference between their employees regarding their training.

The companies utilized several methods to solve the replacement of their employees. These methods included hiring a new colleague (39.7\%), restructuring $(30.6 \%)$ and dividing the tasks $(25.6 \%)$. There was no connection between the methods and the type of specialized knowledge which the organizations expected from their employees.

When a young mother goes on maternity leave, her tasks and knowledge are transferred with the help of a person whose position differed at every organization. Typically, the pregnant employee shared her tasks and the attached knowledge herself $(41.6 \%)$, or a mentor was given this duty $(32.7 \%)$. There were a few companies where nobody cared about this problem, thinking that no training was necessary $(11.9 \%)$. During the research, one of the questions was whether there was any correlation between the necessity of having specialized knowledge within the organization and the person who is in charge of knowledge transfer in this situation. The results showed that there was only significant connection where the companies decided that they did not need this type of knowledge management. This meant that when there was a need for specialized knowledge at the organization, only $5.7 \%$ had no person responsible for knowledge transfer in similar situations, as opposed to the organizations where there was no need for specialized knowledge, in which case $22.2 \%$ did not have a separate person for the task (Pearson Chi-square test: 4.208 df: 1 sign.: $0.040 \mathrm{p}<0.05$ ).

The tool used for knowledge transfer was the help of the mother of young children in $29.5 \%$ of the cases; there was a documented process description at several companies (26.4\%), while others hired mentors (24.8\%). 3,1\% of the companies used other methods, while $9.3 \%$ made no such steps whatsoever. Only in this last case was a significant connection between the applied method and the expectation for specialized knowledge (Pearson Chi-square: 4.208, df: 1 sign.: $0.040 \mathrm{p}<0.05$ ). Most of the companies (38.8\%) spent less than 2 weeks replacing their pregnant employee, while one organization out of five was willing to spend more than a month on this task. At the same time, $11.3 \%$ of the examined companies did not spend any time on this process at all.

It was interesting to see that only $15 \%$ of the companies saw any danger of knowledge loss in this situation. In this respect, there was no difference between the companies who expected specialized knowledge and those who did not. 
Finally, approximately $40 \%$ of the companies claimed that they had a developed protocol to replace their employees on maternity leave or to successfully transfer their task. At the same time, the research indicated that there was no significant correlation between the existence of such a protocol and what kind of knowledge the organizations expected from their employees.

\section{Discussion}

This study is presenting the tasks and questions appearing during the intraorganizational knowledge transfer of an employee going on maternity leave; during the research, the points of view of both the employees and the employers were taken into consideration. As we could not find any earlier research dealing with this particular situation (going on and returning from maternity leave), the basis for comparing the results with the research found in the professional literature is not provided by previous research but by this research, that is, the process of knowledge transfer.

The hypothesis made during the research with the mothers of young children could not be accepted because the success of knowledge transfer was not influenced by either the career prospects or the position the mother filled before her pregnancy. On the one hand, this contradicts our own experience and our previous research results; on the other hand, the results of international research does not support it either [11] as those results prove that the lack of willingness to share knowledge can, in most cases, be traced back to fear about the individual's career [24].

Generally, it can be said that most women accepted the importance of knowledge transfer in this life situation, although they also clearly saw that they could not pass all their knowledge during the process. This primarily meant that part of their knowledge which could not be handled by mere documentation or by using informatics. The studies indicate that even if there is knowledge transfer in such a case, it is mostly restricted to the information which they are obliged to share and, consequently, it lacks the elements of tacit knowledge.

At the same time, the findings of this research coincided with previous research [21], that is, the women were not necessarily motivated to share their knowledge. They felt that a certain amount of knowledge monopoly may ensure that their knowledge could represent further value to their organization on their return to work. This is more identical to the results seen in other research presented in the professional literature [27].

Their motivation was especially influenced by the fact that a lot of them were not sure whether they could return to work after a long period of absence. This kind of uncertainty often results in mistrust, which, as it was shown in the professional 
literature, may be one of the greatest hindering factors for a successful knowledge transfer.

The most recent Hungarian study [29] done by KPMG in 2013-14 also supports this claim.

A high portion of the women taking part in this research (44.9\%), stayed at home for 3 or more years, and this long period of absence clearly deteriorated their chances of any re-integration to their previous workplace. This was also verified by earlier research [26] a long absence, coupled with the questions of reconciling work and family life, can greatly influence employers decision whether to employ these women who typically fail to meet the requirements. The current research also showed, however, that those women with future career prospects or higher positions at their previous organizations returned to the world of work sooner than those people with no such advantages.

The research conducted with the organizations showed that there was no typical connection between the expectation for specialized knowledge and the success of knowledge transfer and protocol when one of their employees goes on maternity leave. This means that the original hypothesis is not valid. The research also verified that most organizations do not possess a developed procedure in similar cases. As this protocol is missing from the corporate knowledge management practice, it does not become part of corporate culture either, which otherwise provides a shield for successful knowledge management. The truth is, most organizations are already considering the necessity of knowledge management strategy building and are already utilizing some of the relevant tools in their work, but only a small percentage of the organizations interviewed by the professional literature claimed that they incorporated this strategy in their long-term goals and their everyday routine [31].

Experts point out that the task of the traditional HRM must be extended. This means that its role in knowledge economy must be revised inside and outside the organization as well [15]. Several organizations interviewed in our research were only in a very initial phase in this respect.

The fact that many companies have no such protocol concerning knowledge sharing can be explained as organizations do not really feel the dangers of knowledge loss due to neglectful knowledge transfer, although they are aware that not all knowledge can be transferred even when the effort is made. This result correlates with the results gained from the questionnaires handed out to various co-workers, all of which claim that tacit knowledge can either not be transferred at all or can only be transferred partially. The companies feel the losses, but they have not yet reached the point where they also feel the economic repercussions of those losses [22].

The knowledge transfer process was also influenced - as shown in the in-depth interviews made by companies - by the degree of complexity the mother of young 
children had to face at work before her pregnancy. In this process, mothers of young children basically acted as mentors, following their replacement's training and passing their knowledge. In the organizations, pregnant women worked for a period of time agreed with the organization. In this case, there were two basic practices: the pregnant mother could continue to work alone and her replacement only arrived after she had left or the mother could stay at work and do her tasks together with her replacement during the training period. Where the mother was not involved in the training, the organization typically hired a mentor or nobody bothered with the issue: this way, the degree of knowledge loss was not - and could not be - assessed properly. The utilization of the mentoring system has a long history, although its application is often superficial and serves only to share explicit knowledge; the connections rarely run deep enough to allow for long-term cooperation and tacit knowledge sharing as well [8].

It is a highly debated topic in the professional literature concerning how much knowledge can be tied to individuals and to what degree this information be passed on to an organization. The current research can be considered unique because it was conducted in an environment which suited the typical conditions in Hungary; however, it is clearly visible that several knowledge element types with emotional intelligence among them - cannot or can only be partially shared. Our research conducted last year was aimed at the connections between emotional intelligence and knowledge sharing, and the results clearly showed that organizations which pay attention to emotional intelligence are also able to function better regarding knowledge sharing [7].

In this situation the success of knowledge management processes should be based on communication and trust, which presupposes the cooperation between women going on maternity leave and the organizations. Thus, if the organizations know what can be lost if a colleague leaves the organization, not only temporarily, or the employee feels and understands that her knowledge can stay current within the organization, then the loss, that can be generated in such a situation, could be reduced on both sides.

\section{Conclusion}

Knowledge sharing is a basic requirement in an organization's life. This is also true of the special case examined in our research. However, the surroundings, the supervision, the quality and the final usefulness of the above mentioned knowledge sharing, are not well thought out. The factors which play an important role, here are connected to soft skills, human relations, trust, managerial behavior and the organizational structure. It is the HR area which can be most helpful in these areas. Women who leave organizations for a certain period of time should be prepared for their leave, and the organization should keep in touch with them even during their stay at home. Also, steps should be taken to ensure that these women can keep their knowledge up to date to be able to return to work after their leave. The conditions of knowledge transfer and the time allowed for it should be 
calculated in every case to meet the requirements of the organization and, in particular, the position. While it is true that most of the respondents are aware of the ever increasing role of such knowledge transfer-stimulating methods and tools like informatics, HR tools, coach-type leadership, new structural organizational forms etc., at the same time, there does not seem to be a genuine breakthrough towards forming a real knowledge sharing culture. On the contrary, we tend to make our own knowledge hidden from the public while paradoxically, we expect the opposite behavior from others. Although it is clearly seen that the organizations of the future look at knowledge as a strategic resource, this vision is not translated into a conscious knowledge management strategy. The next line of research is going to aim in the exploration of the background of this basic contradiction: how are the ethical values of the companies implemented, how is internal knowledge sharing solved and finally, how effectively can these systems operate?

As far as the barriers for the present study are concerned (besides the lack of preparation of the involved organizations), we also have to mention that the willingness to answer was generally very low, not all the regions were available in the same degree and mothers on maternity leave did not speak about their situation with pleasure, as their returning to the labor market is difficult, anyway. We hope that we can carry out following research under more favorable conditions.

\section{References}

[1] Abrams, L. C., Cross, E., Lesser, K., Levin, D. Z.: 'Nurturing Interpersonal Trust in Knowledge-Sharing Networks', Academy of Management Executive 17, 4, pp. 64-77. 2003

[2] Alston, F., Tippett, D.: 'Does a Technology-driven Organization's Culture Influence the Trust Employees Have in their Managers?', Engineering Management Journal 21, 2, pp. 3-10. 2009

[3] Argote, L., and Ingram, P.: 'Knowledge Transfer: a Basis for Competitive Advantage in Organisations', Organizational Behaviour and Human Decision Process 82, 150-169. 2000

[4] Bálint, M., Köllő, J.: 'Labor-Market Effects of Child-Care Support' ('A gyermekgondozási támogatások munkaerő-piaci hatásai') Esély, 1-21, 2007

[5] Bakacsi, Gy., Bokor, A., Császár, Cs., Gelei, A., Kováts, K., Takács, S.: 'Stratégiai emberi erőforrás menedzsment', Budapest, Hungary: KJKKERSZÖV Jogi és Üzleti Kiadó Kft. 2000

[6] Bencsik, A., Juhász, T.: 'A nők visszailleszkedése a munkaerő-piacra a gyermekvállalás után', in: Útkeresés az üzleti és a közszférában, KHEOPS Scientific Conference Proceedings, 287-296. 2009

[7] Bencsik, A., Stifter, V., Sólyom, A.: 'Examining Tacit Knowledge Transfer at Hungarian Organizations' ('A tacit tudás átadásának vizsgálata magyarországi szervezeteknél', in: Aktuális gazdasági és társadalmi 
attitüdök Magyarországon, KHEOPS Scientific Conference Proceedings, 185-195, 2012

[8] Bencsik, A., Stifter, V.: Mentor System Rights in Knowledge Sharing, Humánpolitikai Szemle, 5, pp. 3-16, 2012

[9] Bencsik, A.: Change, Project, Knowledge - Symbiosis of Change and Project Management to Build a Knowledge Management System, LAP Lambert Academic Publishing Germany 2012

[10] Bencsik, A.: Best practice a tudásmenedzsment rendszer kiépítésében, avagy Tudásmenedzsment kézikönyv menedzserek számára. Pearson Publishing Harlow England, 2013

[11] Berends, H., van der Bij, H., Debackere, K., Weggeman, M.: 'Knowledge Sharing Mechanisms in Industrial Research', R\&D Management 36, 1, 8595, 2006

[12] Boon, S. D., Holmes, J. G.: 'The Dynamics of Interpersonal Trust: Resolving Uncertainty in the Face of Risk', in: Cooperation and Prosocial Behaviour Hinde, eds. R.A. and Groebel, J., Cambridge, UK. Cambridge University Press, pp. 190-211, 1991

[13] Bőgel, Gy.: 'Tudás, pénz, hatalom' I.-II. CEO, 6, 1/2. 8-15, pp. 27-33, 2005

[14] Branzei, O., Vertinsky, I., Camp, R. D.: 'Culturecontingent Signs of Trust in Emergent Relationships', Organizational Behaviour and Human Decision Processes 104, 1, pp. 61-82, 2007

[15] Chivu, J., Popescu D.: 'Human Resources Management in the Knowledge Management', Informatica Economica, 13, pp. 54-60, 2008

[16] Cook, J., Wall, T.: 'New Work Attitude Measures of Trust, Organizational Commitment and Personal Need Nonfulfillment', Journal of Occupational Psychology 53, pp. 39-52, 1980

[17] Davenport, T. H., and Prusak, L. (1998) 'Working Knowledge: How Organisations Manage What They Know', Boston, MA: Harvard Business School Press 1998

[18] Davenport TH., Prusak L.: 'Knowledge management' ('Tudásmenedzsment') Budapest, Hungary, Kossuth Kiadó 2001

[19] De Long D. W., Fahey, L.: 'Diagnosing Cultural Barriers to Knowledge Management', The Acadaemy of Management Executive, 43, pp. 113-127, 2000

[20] Dittmar, J., Jennings, K., Stahl-Wert, J.: 'Trust and Engagement', Leadership Excellence 24, 11, p. 8, 2007

[21] Dobrai, K., Farkas, F., Karoliny, Zs., Poór, J.: Knowledge Transfer in Multinational Companies - Evidence from Hungary, Acta Polytechnica Hungarica, 9, 3, pp. 149-161, 2012 
[22] Hafiza, A., Merduwati, D., Adnan, J., Sa'ari, H.: Challenge in Sharing Tacit Knowledge, in: Academicians' Behavior Towards Developing a Web Portal for Sharing Research Ideas, Proceedings of the European Conference on Information Management, pp. 337-348, 2013

[23] Heasli, A., Boxall, P.: 'When Knowledge Management Meets HR Strategy: an Exploration of Personalization-Retention and Codification-Recruitment Configurations', The Intenational Journal of Human Resource Management, pp. 1955-1975, 2005

[24] Hsiu-Fen, L.: 'Knowledge Sharing and Organisation Innovation Capability: an Empirical Study', International Journal of Manpower 28, 3/4, pp. 315332,2007

[25] Hvorecky, J. Simuth, J., Lichardus, B.: Managing Rational and Not-FullyRational Knowledge, Acta Polytechnica Hungarica, 10, 2, pp. 121-132, 2013

[26] Juhasz, T.: 'Családbarát munkahelyek, családbarát szervezetek', unpublished PhD Dissertation, Széchenyi István University, 2010

[27] 'Knowledge Sharing in the European Research Area': (ERA) Report of the ERA Expert Group, Luxembourg: Office for Official Publications of the European Communities. 2008

[28] Kő, A., Vas, R., Molnár, B.: 'Az információs társadalom tudástranszfer innovatív módjai', Budapest, Hungary: MTA Információtechnológiai Alapítvány, 2003

[29] KPMG Academy: 'Organizational Knowledge Sharing in Hungary 20132014' ('Szervezeti tudásmegosztás Magyarországon 2013-14') Research report, 2014

[30] KSH: ‘A válság munkaerö-piaci következményei 2010-2011 I. félév’, pp. $1-15,2011$

[31] Lee, Ch. F., Tsai, S. D., Amjadi, M.: 'The Adaptive Approach: Reflections on Knowledge Management Models', Journal of Management Inquiry 21, 30 , originally published online $1^{\text {st }}$ June 2011

[32] Leonards, D.: 'Core Capabilities and Core Rigidities A paradox in Managing New Product Development, Strategic Management Journal pp. $111-125,1992$

[33] Polányi, M.: Personal Knowledge-Towards a Post Critical Philosophy, London, UK: Routledge and Kegan Paul, 1962 